\title{
The International Union of Immunological Societies (IUIS) Primary Immunodeficiency Diseases (PID) Classification Committee
}

Raif. S. Geha, M.D., Luigi. D. Notarangelo, M.D. [Co-chairs], Jean-Laurent Casanova, M.D., Helen Chapel, M.D., Mary Ellen Conley, M.D., Alain Fischer, M.D., Lennart Hammarström, M.D., Shigeaki Nonoyama, M.D., Hans D. Ochs, M.D., Jennifer Puck, M.D., Chaim Roifman, M.D., Reinhard Seger, M.D., and Josiah Wedgwood, M.D.

\begin{abstract}
Primary immune deficiency diseases (PID) comprise a genetically heterogeneous group of disorders that affect distinct components of the innate and adaptive immune system, such as neutrophils, macrophages, dendritic cells, complement proteins, NK cells, as well as T and B lymphocytes. The study of these diseases has provided essential insights into the functioning of the immune system. Over 120 distinct genes have been identified, whose abnormalities account for more than 150 different forms of PID. The complexity of the genetic, immunological, and clinical features of PID has prompted the need for their classification, with the ultimate goal of facilitating diagnosis and treatment. To serve this goal, an international Committee of experts has met every two years since 1970. In its last meeting in Jackson Hole, Wyoming, United States, following three days of intense scientific presentations and discussions, the Committee has updated the classification of PID as reported in this article.
\end{abstract}

\section{Keywords}

Primary Immunodeficiency diseases; T cells; B cells; phagocytes; complement; immune dysregulation syndromes; innate immunity

Following the original invitation by the World Health Organization in 1970, a Committee of experts in the field of Primary Immune Deficiencies (PID) has met every two years with the goal of classifying and defining this group of disorders. The most recent meeting, organized under the aegis of the International Union of Immunological Societies (IUIS), with support from the Jeffrey Modell Foundation and the National Institute of Allergy and Infectious Diseases (NIAID) of the National Institutes of Health, took place in Jackson Hole, Wyoming, USA, in June 2007. In addition to members of the Experts Committee, the meeting gathered more than 30 speakers and over 150 participants from six continents. Recent updates in the molecular and cellular pathophysiology of PID were reviewed and provided the basis for updating the classification of PID.

After an opening lecture in which Tom Waldmann, a founding member of the Committee, highlighted some of his most remarkable achievements in the fields of PID and tumor

Correspondence to: Raif S. Geha or Luigi Notarangelo, Division of Immunology, Children's Hospital, One Blackfan Circe, Boston, MA 02115, Tel: 617-919-2482 Fax: 617-730-0528 e-mail: raif.geha@ childrens.harvard.edu or luigi.notarangelo@ childrens.harvard.edu.

Publisher's Disclaimer: This is a PDF file of an unedited manuscript that has been accepted for publication. As a service to our customers we are providing this early version of the manuscript. The manuscript will undergo copyediting, typesetting, and review of the resulting proof before it is published in its final citable form. Please note that during the production process errors may be discovered which could affect the content, and all legal disclaimers that apply to the journal pertain. 
immunology, Kenneth Murphy reviewed the signals that govern helper T cell development and differentiation into Th1, Th2, and Th17 cells. This paved the way to presentations by Bill Paul and Anna Villa, who illustrated how two different mechanisms (i.e., homeostatic proliferation of $\mathrm{CD}^{+} \mathrm{T}$ cells in a lymphopenic host, and impaired central and peripheral tolerance in mice with hypomorphic defects of $\mathrm{V}(\mathrm{D}) \mathrm{J}$ recombination) may lead to similar phenotypic manifestations, that mimic Omenn syndrome ${ }^{1,2}$. The expanding field of genes involved in $\mathrm{V}(\mathrm{D}) \mathrm{J}$ recombination, class switch recombination and DNA repair, was reviewed by Jean Pierre de Villartay (who has reported on Cernunnos deficiency) ${ }^{3}$ and Dick van Gent (DNA ligase 4 deficiency) ${ }^{4}$, while Fred Alt illustrated how these and other defects may lead to generalized genomic instability 5 and contribute also to tumor development. Later in the meeting, Qiang Pan-Hammarström expanded on chromosome instability syndromes, and in particular on the role played by ATM, the gene mutated in Ataxia-Telangiectasia, in DNA repair ${ }^{6}$.

John Ziegler reported on a recently identified form of PID, familial hepatic veno-occlusive disease and immunodeficiency (VODI), a combined immunodeficiency due to mutations of the SP110 gene, a component of PML nuclear bodies ${ }^{7}$. Stefan Feske presented his work on cloning of the ORAII gene, which encodes for an integral component of calcium channels, whose mutations lead to a severe combined immune deficiency in which $\mathrm{T}$ cell development is not arrested but peripheral T cells are unresponsive to proliferative signals ${ }^{8}$. Genevieve de Saint Basile discussed the basic mechanisms involved in cell-mediated cytotoxicity, and especially generation and trafficking of exocytic vescicles and cytolytic granules, as unraveled through the study of human models of impaired cytotoxicity ${ }^{9}$. Dale Umetsu reviewed the biology of Natural Killer T (NKT) cells, and Sylvain Latour described a novel form of X-linked lymphoproliferative disease, due to mutations of the XIAP (X-linked inhibitor of apoptosis) gene, in which impaired apoptosis is associated with a severe decrease of NKT cells in the periphery 10 .

Amos Etzioni reported on Leukocyte Adhesion Deficiency type 3 (LAD3), a disease characterized by impaired inside-out integrin signaling in leukocytes and platelets, due to mutations of the CALDAG-GEF1 gene ${ }^{11}$. The different requirement for $\mathrm{T}$ and $\mathrm{B}$ cell immunological memory by cytopathic vs. non cytopathic viruses, and the possible need for persistence/boosting with antigen in this process, were reviewed by Rolf Zinkernagel.

In the last year, major advances have been achieved in the molecular and cellular characterization of hyper-IgE syndrome. Hajime Karasuyama gave an update on mutations of the TYK2 gene, and abnormal cytokine-mediated signaling, in an autosomal recessive form of the disease ${ }^{12}$. Steven Holland reported that heterozygous mutations of STAT3 account for the more common autosomal dominant form of the disease, a previously unwknown finding also confirmed by the group of Karasuyama ${ }^{13}$. Two young investigators, Lilit Garibyan and Lalit Kumar, discussed the molecular mechanisms of TACI deficiency (providing evidence for intracellular pre-assembly of high-order multimers of the protein) ${ }^{14}$ and the phenotype of $L R R C 8$ knock-out mice, respectively.

Exciting results have recently appeared on the molecular and cellular characterization of severe congenital neutropenia (SCN). Cristoph Klein reported on the identification of two such defects: mutations of $14^{15}$, an endosomal scaffold protein, and of HAX1 16 , involved in control of apoptosis. The inflammasome was reviewed by Nunez, who showed that both gainof-function and loss-of-function mutations of NOD-like receptors (NLR) may cause disease in humans. Nunez especially focused on the interplay between pathogens and molecules of the innate immunity system ${ }^{17}$. Jean-Laurent Casanova reported on an unusual phenotype associated with mutations of the CYBB gene (that usually cause chronic granulomatous disease), thus further illustrating the importance of studying human patients to unravel novel 
molecules and functions within the immune system. The interplay between molecules of the immune system and pathogens was also discussed by Cox Terhorst, who reported on the role played by SLAM and SLAM family members in controlling bacterial infections. Michael Carroll illustrated the role played by complement in governing memory B cell responses, whereas Peter Zipfel discussed how defects of the alternative pathway may lead to kidney disease $^{18}$.

Immunodysregulatory disorders were introduced by Sasha Rudensky, who discussed the development and biology of regulatory T cells. Scott Snapper showed how mutations in WASP lead to inflammatory bowel disease in mice. Alberto Bosque presented novel data on Fas ligand (FasL) mutations in a subgroup of patients with autoimmune lymphoproliferative syndrome (ALPS), that result in impaired Bim expression and hence in decreased apoptosis ${ }^{19}$. Richard Siegel discussed the molecular mechanisms involved in TRAPS, and showed that retention of TRAPS-associated mutant TNF-receptor 1 (TNFR1) molecules in the endoplasmic retyculum results in ligand-independent signaling 20 .

In his concluding remarks, Alain Fischer summarized the heuristic value of PID. He pointed out that a substantial number of immune genes have been discovered (even in recent years) through the study of patients with PID, whereas for many others the function has been clarified or revealed) through the careful study of human patients. While PID have been traditionally viewed as predisposing to a broad range of infectious pathogens, more and more examples are being identified in which they cause selective susceptibility to single pathogens. Furthermore, PID have illustrated the multiple pathways (impaired negative selection, defective development/function of regulatory $\mathrm{T}$ cells, perturbed apoptosis of self-reacive lymphocytes in the periphery) that may cause autoimmunity. Much more than generation of artificial models in mice, the study of humans with PID has demonstrated the variability of phenotypes that may associate with distinct mutations in the same gene. As Fischer emphasized, it is now time to look at novel approaches to therapy for PID, based on the study of disease mechanisms. This is not restricted to gene therapy, but also includes bypassing biochemical and/or cellular defects (as shown by the use of IFN- $\gamma$ in familial mycobacteriosis), and exploiting the use of chemical compounds to allow reading-through nonsense mutations or correction of splice-site mutations.

At the end of the meeting, the IUIS Expert Committee met to update the classification of PID, as presented in Table $1-8$.

\section{ACKNOWLEDGMENT}

We thank Dr. Richard Siegel (NIAIM, NIH, Bethesda, MD, USA) for his contribution of Table 7 and Ms. Sayde ElHachem for invaluable assistance in constructing the Tables.

The Jackson Hole meeting was partially supported by the Jeffrey Modell Foundation and by the NIAID grant R13AI-066891. Preparation of this report was supported in part by a European Union Euro-Policy-PID grant to L.D. N. and by NIH grant AI-35714 to R.S.G.

\section{References}

1. Marrella V, Poliani PL, Casati A, Rucci F, Frascoli L, Gougeon ML, et al. A hypomorphic R229Q Rag2 mouse mutant recapitulates human Omenn syndrome. J Clin Invest 2007;117:1260-1269. [PubMed: 17476358]

2. Milner JD, Ward JM, Keane-Myers A, Paul WE. Lymphopenic mice reconstituted with limited repertoire T cells develop severe, multiorgan, Th2-associated inflammatory disease. Proc Natl Acad Sci USA 2007;104:576-581. [PubMed: 17202252]

3. Buck D, Malivert L, de Chasseval R, Barraud A, Fondaneche MC, Sanal O, et al. Cernunnos, a novel nonhomologous end-joining factor, is mutated in human immunodeficiency with microcephaly. Cell 2006;124:287-299. [PubMed: 16439204] 
4. Van der Burg M, van Veelen LR, Verkaik NS, Wiegant WW, Hartwig NG, Barendregt BH, et al. A new type of radiosensitive $\mathrm{T}^{-} \mathrm{B}^{-} \mathrm{NK}^{+}$severe combined immunodeficiency caused by a LIG4 mutation. J Clin Invest 2006;116:137-145. [PubMed: 16357942]

5. Zha S, Alt FW, Cheng HL, Brush JW, Li G. Defective DNA repair and increased genomic instability in Cernunnos-XLF-deficienct murine ES cells. Proc Natl Acad Sci USA 2007;104:4518-4523. [PubMed: 17360556]

6. Pan-Hammarstrom Q, Lahdesmaki A, Zhao Y, Du L, Zhao Z, Wen S, et al. Disparate roles of ATR and ATM in immunoglobulin class switch recombination and somatic hypermutation. J Exp Med 2006;203:99-110. [PubMed: 16390936]

7. Roscioli T, Cliffe ST, Bloch DB, Bell CG, Mullan G, Taylor PJ, et al. Mutations in the gene encoding the PML nuclear body protein Sp110 are associated with immunodeficiency and veno-occlusive disease. Nat Genet 2006;38:620-622. [PubMed: 16648851]

8. Feske S, Gwack Y, Prakriya M, Srikanth S, Puppel SH, Tanasa B, et al. A mutation in Orai1 causes immune deficiency by abrogating CRAC channel function. Nature 2006;441:179-185. [PubMed: 16582901]

9. Menager MM, Menasche G, Romao M, Knapnougel P, Ho CH, Garfa M, et al. Secretory cytotoxic granule maturation and exocytosis require the effector protein hMunc13-4. Nat Immunol 2007;8:257267. [PubMed: 17237785]

10. Riagud S, Fontaneche MC, Lambert N, Pasquier B, Mateo V, Soulas P, et al. XIAP deficiency in humans causes an X-linked lymphoproliferative syndrome. Nature 2006;444:110-114. [PubMed: 17080092]

11. Pasvolsky R, Feigelson SW, Kilic SS, Simon AJ, Tal-Lapidot G, Grabovsky V, et al. A LAD-III syndrome is associated with defective expression of the Rap-1 activator CalDAG-GEFI in lymphocytes, neutrophils, and platelets. J Exp Med 2007;204:1571-1582. [PubMed: 17576779]

12. Minegishi Y, Saito M, Morio T, Watanabe K, Agematsu K, Tsuchiya S, et al. Human tyrosine kinase 2 deficiency reveals its requisite roles in multiple cytokine signals involved in innate and acquired immunity. Immunity 2006;25:745-755. [PubMed: 17088085]

13. Minegishi Y, Saito M, Tsuchiya S, Tsuge I, Takada H, Hara T, et al. Dominant-negative mutations in the DNA-binding domain of STAT3 cause hyper-IgE syndrome. Nature. 2007 Aug 5; [Epub ahead of print]

14. Garibyan L, Lobito AA, Siegel RM, Call ME, Wucherpfennig KW, Geha RS. Dominant-negative effect of the heterozygous C104R TACI mutation in common variable immunodeficiency (CVID). J Clin Invest 2007;117:1550-1557. [PubMed: 17492055]

15. Bohn G, Allroth A, Brandes G, Thiel J, Glocker E, Schaffer AA, et al. A novel human primary immunodeficiency syndrome caused by deficiency of the endosomal adaptor protein p14. Nat Med 2007;13:38-45. [PubMed: 17195838]

16. Klein C, Grudzien M, Appaswamy G, Germeshausen M, Sandrock I, Schaffer AA, et al. HAX1 deficiency causes autosomal recessive severe congenital neutropenia (Kostmann disease). Nat Genet 2007;39:86-92. [PubMed: 17187068]

17. Kanneganti TD, Ozoren N, Body-Malapel M, Amer A, Park JH, Franchi L, et al. Bacterial RNA and small antiviral compounds activate caspase-1 through cryopyrin/Nalp3. Nature 2006;440:233-236. [PubMed: 16407888]

18. Zipfel PF, Edey M, Heinen S, Jozsi M, Richter H, Misselwitz J, et al. Deletion of complement factor H-related genes CFHR1 and CFHR3 is associated with atypical hemolytic uremic syndrome. PloS Genet 2007;3:e41. [PubMed: 17367211]

19. Bosque A, Aguilo JI, Alava MA, Paz-Artal E, Naval J, Allende LM, et al. The induction of Bim expression in human T-cell blasts is dependent on nonapoptotic Fas/CD95 signaling. Blood 2007;109:1627-1635. [PubMed: 17062728]

20. Lobito AA, Kimberley FC, Muppidi JR, Komarow H, Jackson AJ, Hull KM, et al. Abnormal disulfidelinked oligomerization results in ER retention and altered signaling by TNFR1 mutants in TNFR1associated periodic fever syndrome (TRAPS). Blood 2006;108:1320-1327. [PubMed: 16684962] 


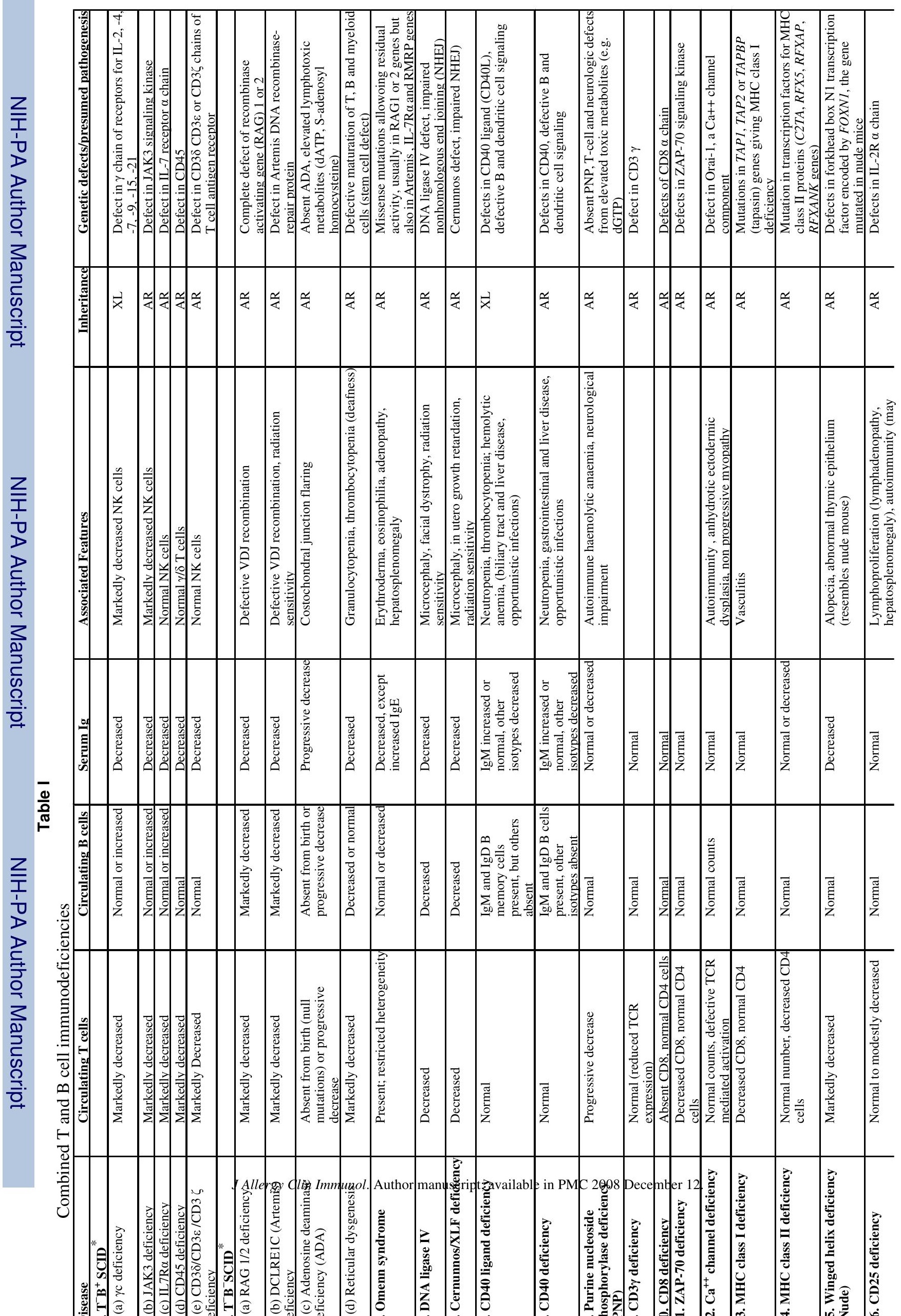




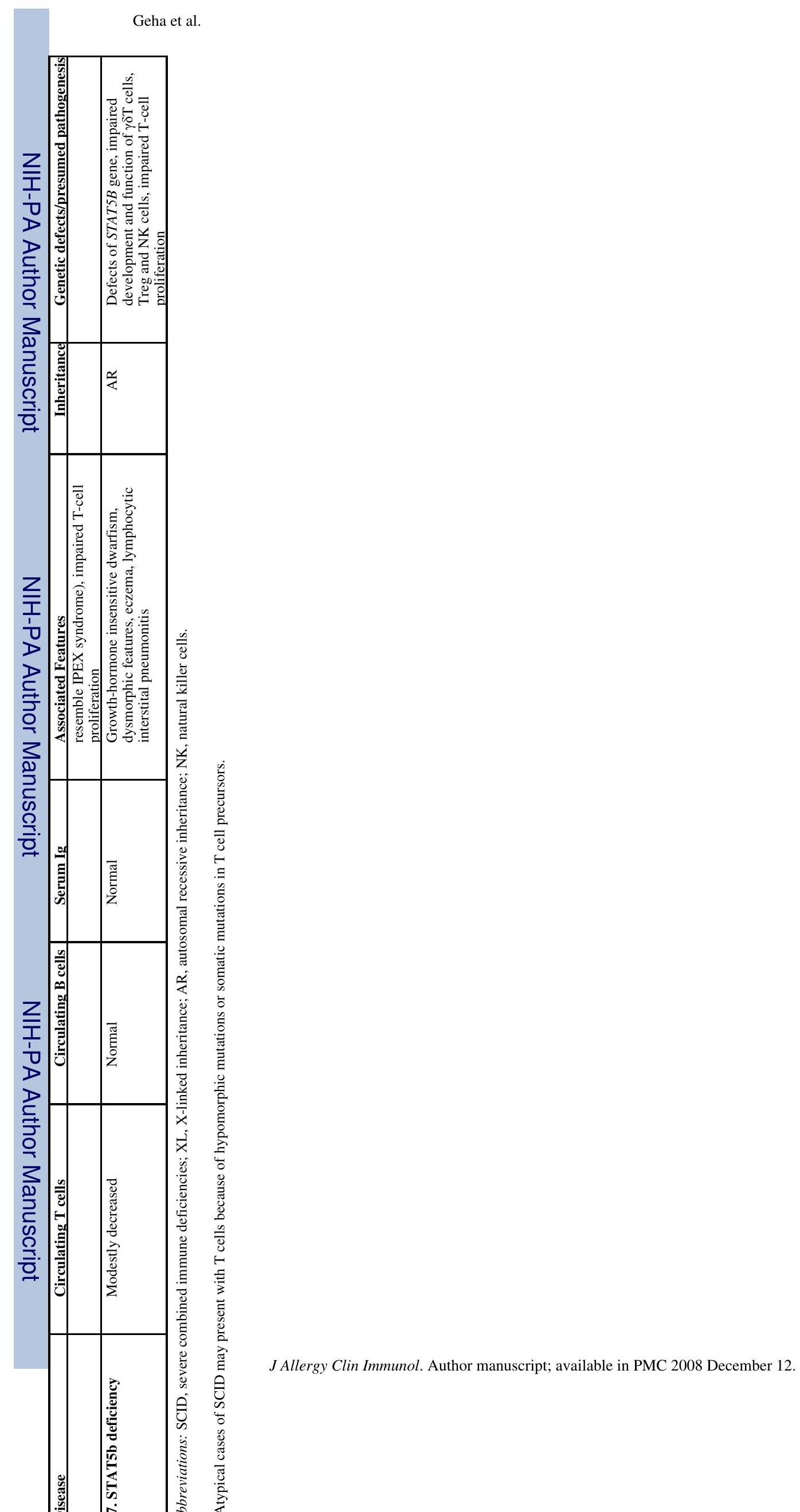

Page 6 
Table II

Predominantly antibody deficiencies

Disease
1. Severe reduction in all serum immunoglobulin isotypes with profoundly decreased or absent B cells

\begin{tabular}{|c|c|c|c|c|}
\hline a) Btk deficiency & All isotypes decreased & $\begin{array}{l}\text { Severe bacterial infections; normal } \\
\text { numbers of pro-B cells }\end{array}$ & XL & Mutations in $B T K$ \\
\hline b) $\mu$ heavy chain deficiency & All isotypes decreased & $\begin{array}{l}\text { Severe bacterial infections; normal } \\
\text { numbers of pro-B cells }\end{array}$ & AR & Mutations in $\mu$ heavy chain \\
\hline c) $\lambda 5$ deficiency & All isotypes decreased & $\begin{array}{l}\text { Severe bacterial infections; normal } \\
\text { numbers of pro-B cells }\end{array}$ & AR & Mutations in $\lambda 5$ \\
\hline e) $\operatorname{Ig} \beta$ Deficiency & All isotypes decreased & $\begin{array}{l}\text { Severe bacterial infections; normal } \\
\text { numbers of pro-B cells }\end{array}$ & $\mathrm{AR}$ & Mutations in $\operatorname{Ig} \beta$ \\
\hline f) BLNK deficiency & All isotypes decreased & $\begin{array}{l}\text { Severe bacterial infections; normal } \\
\text { numbers of pro-B cells }\end{array}$ & AR & Mutations in $B L N K$ \\
\hline h) Myelodysplasia & All isotypes decreased & $\begin{array}{l}\text { Infections; decreased numbers of pro- } \\
\text { B cells }\end{array}$ & Variable & $\begin{array}{l}\text { May have monosomy } 7 \text {, trisomy } 8 \text { or } \\
\text { dyskeratosis congenita }\end{array}$ \\
\hline
\end{tabular}

2. Severe reduction in serum $\mathrm{IgG}$ and $\operatorname{IgA}$ with normal,

low or very low numbers of B cells

$\begin{array}{ll}\text { Common variable } & \text { Low IgG and IgA; } \\ \text { immunodeficiency } & \text { variable IgM }\end{array}$

\section{variable IgM}

Low IgG and $\operatorname{Ig} \mathrm{A}$; normal IgM

Low IgG, IgA and IgM All isotypes may be low

\begin{abstract}
All have recurrent bacterial infections. Clinical phenotypes vary: autoimmune, lymphoproliferative and/or granulomatous disease
a) ICOS deficiency
b) CD19 deficiency
c) XLP1 ${ }^{\text {**** }}$

terial infections; norma

\begin{abstract}
3. Severe reduction in serum IgG and Ig A with normal/ elevated IgM and normal numbers of B cells

a) CD40L deficiency ${ }^{* * * *}$
\end{abstract}

$\begin{array}{ll}\text { b) CD40 deficiency }^{* * * *} & \text { normal or increased } \\ & \text { Low IgG and IgA; } \\ & \text { normal or raised IgM } \\ \text { c) AID deficiency } & \text { IgG and IgA } \\ & \text { decreased; IgM } \\ & \text { increased } \\ \text { d) UNG deficiency } & \text { IgG and IgA } \\ \text { decreased; IgM } & \text { increased }\end{array}$

4. Isotype or light chain deficiencies with normal numbers of B cells

a) Ig heavy chain deletions

b) $\mathrm{k}$ chain deficiency

c) Isolated IgG subclass deficiency

d) $\operatorname{IgA}$ deficiency associated with IgG subclass deficiency e) Selective IgA deficiency

\section{IgG and IgA decreased; IgM may be normal or increased; B cell numbers may be Low IgG and IgA; mal or raised IgM increased}

Opportunistic infections, neutropenia, autoimmune disease

XL

Approximately positive family history (AR or

AD)

AR

XL Mutations in SH2D1A $10 \%$ have a

AR $\quad$ Mutations in $C D 19$
Alterations in TACI, BAFFR, Msh5 may act as contributing polymorphisms

Mutations in $I C O S$

$\begin{array}{lll}\begin{array}{l}\text { Opportunistic infections, neutropenia } \\ \begin{array}{l}\text { Enlarged lymph nodes and germinal } \\ \text { centres }\end{array}\end{array} & \text { AR } & \begin{array}{l}\text { Mutations in } C D 40 \text { (also called } \\ \text { TNFRSF5) } \\ \text { Mutations in AICDA gene }\end{array} \\ \begin{array}{l}\text { Enlarged lymph nodes and germinal } \\ \text { centres }\end{array} & \text { AR } & \text { Mutations in } U N G \text { gene }\end{array}$
centres

\begin{tabular}{|c|c|c|c|}
\hline $\begin{array}{l}\text { One or more IgG and/ } \\
\text { or IgA subclasses as } \\
\text { well as IgE may be } \\
\text { absent }\end{array}$ & May be asymptomatic & AR & Chromosomal deletion at $14 \mathrm{q} 32$ \\
\hline $\begin{array}{l}\text { All immunoglobulins } \\
\text { have lambda light } \\
\text { chain }\end{array}$ & Asymptomatic & AR & Mutations in kappa constant gene \\
\hline $\begin{array}{l}\text { Reduction in one or } \\
\text { more IgG subclass }\end{array}$ & $\begin{array}{l}\text { Usually asymptomatic; may have } \\
\text { recurrent viral/bacterial infections }\end{array}$ & Variable & Unknown \\
\hline $\begin{array}{l}\text { Reduced IgA with } \\
\text { decrease in one or } \\
\text { more IgG subclass }\end{array}$ & $\begin{array}{l}\text { Recurrent bacterial infections in } \\
\text { majority }\end{array}$ & Variable & Unknown \\
\hline IgA decreased/absent & $\begin{array}{l}\text { Usually asymptomatic; may have } \\
\text { recurrent infections with poor }\end{array}$ & Variable & Unknown \\
\hline
\end{tabular}


antibody responses to carbohydrate antigens; may have allergies or

autoimmune diseases.

A few cases progress to CVID, others

coexist with CVID in the same family.

\begin{tabular}{|c|c|c|c|c|}
\hline $\begin{array}{l}\text { 5. Specific antibody } \\
\text { deficiency with normal Ig } \\
\text { concentrations and normal } \\
\text { numbers of B cells }\end{array}$ & Normal & $\begin{array}{l}\text { Inability to make antibodies to } \\
\text { specific antigens }\end{array}$ & Variable & Unknown \\
\hline $\begin{array}{l}\text { 6. Transient } \\
\text { hypogammaglobulinemia }\end{array}$ & IgG and $\operatorname{IgA}$ decreased & $\begin{array}{l}\text { Recurrent moderate bacterial } \\
\text { infections }\end{array}$ & Variable & Unknown \\
\hline
\end{tabular}

hypogammaglobulinemia infections

of infancy with normal

numbers of B cells

$X L, \mathrm{X}$-linked inheritance; $A R$, autosomal recessive inheritance; $A D$, autosomal dominant inheritance; $B T K$, Burton tyrosine kinase; BLNK, B cell linker protein; $A I D$, activation-induced cytidine deaminase; $U N G$, uracil-DNA glycosylase; $I C O S$, inducible costimulator; $I g(\kappa)$, immunoglobulin of $\kappa$ lightchain type.

* Common variable immunodeficiency disorders: there are several different clinical phenotypes, probably representing distinguishable diseases with differing immunopathogeneses; alterations in TACI, BAFFR and Msh5 sequences may represent contributing polymorphisms or disease modifying alterations.

$* *$

A disease-causing effect has been identified for homozygous C140R and A181E TACI mutations.

XLP1 (X-linked lymphoproliferative syndrome) is also included in Table IV.

CD40L deficiency (X-linked hyper IgM syndrome) and CD40 deficiency are also included in Table I. 


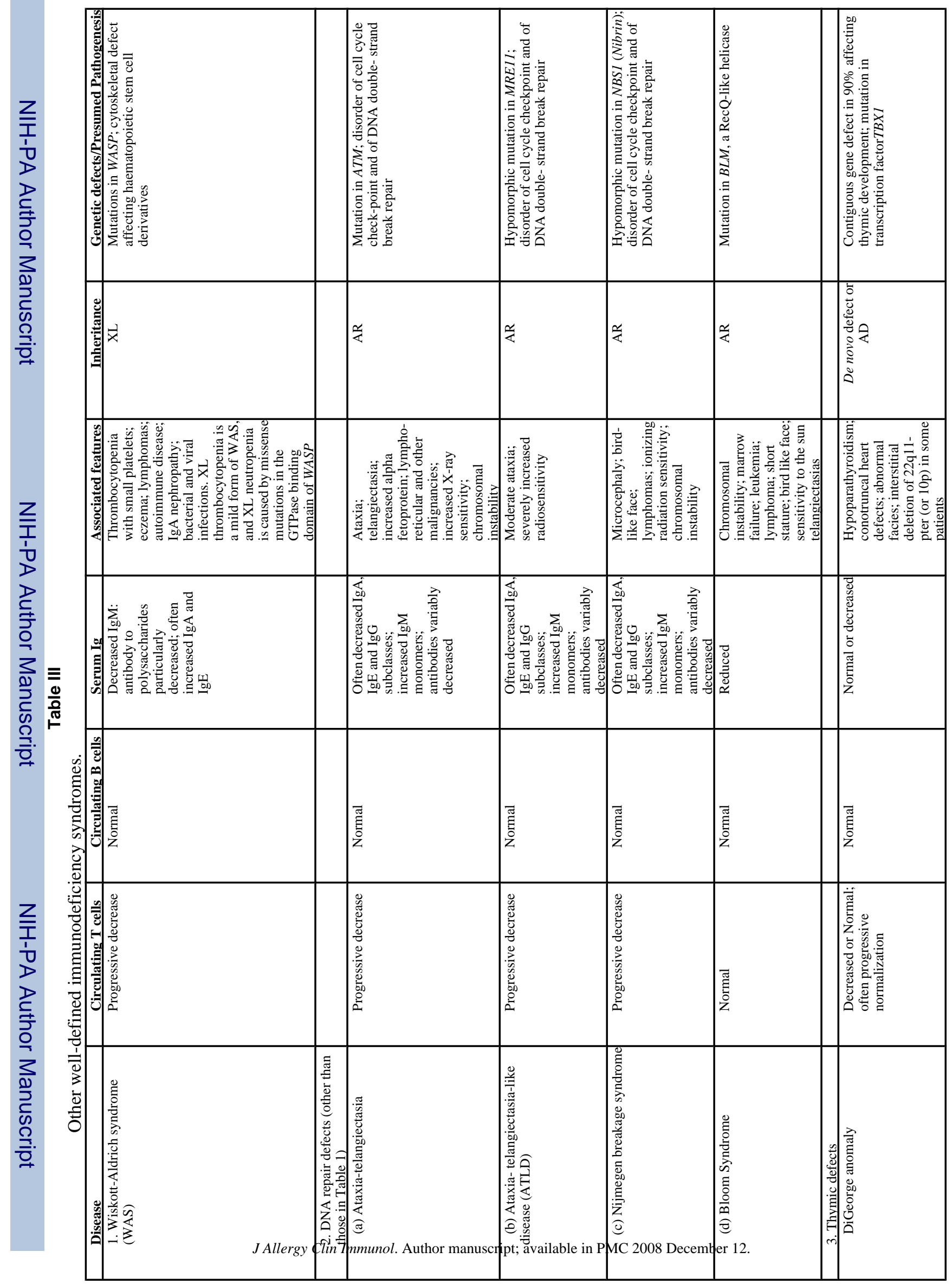




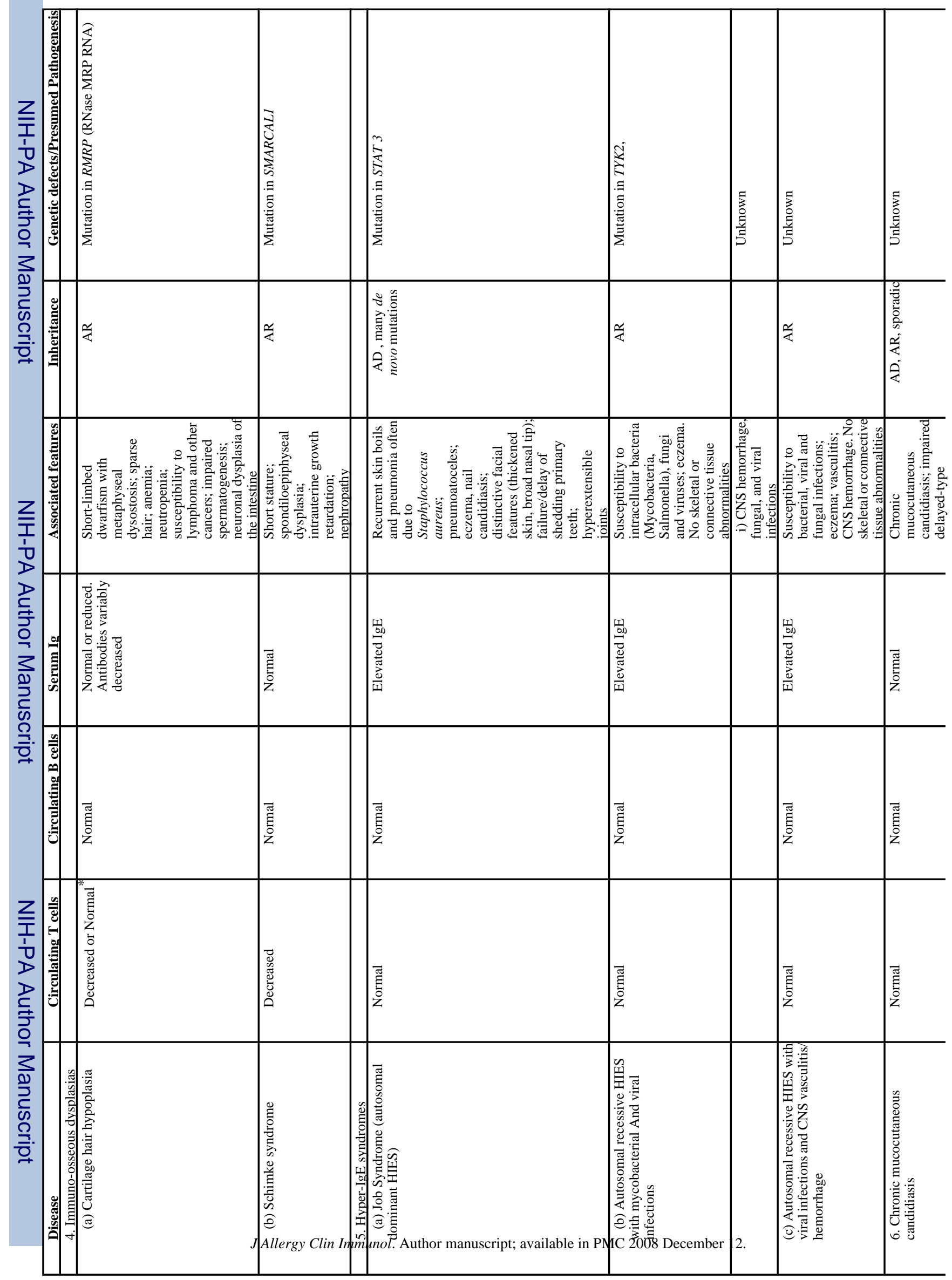




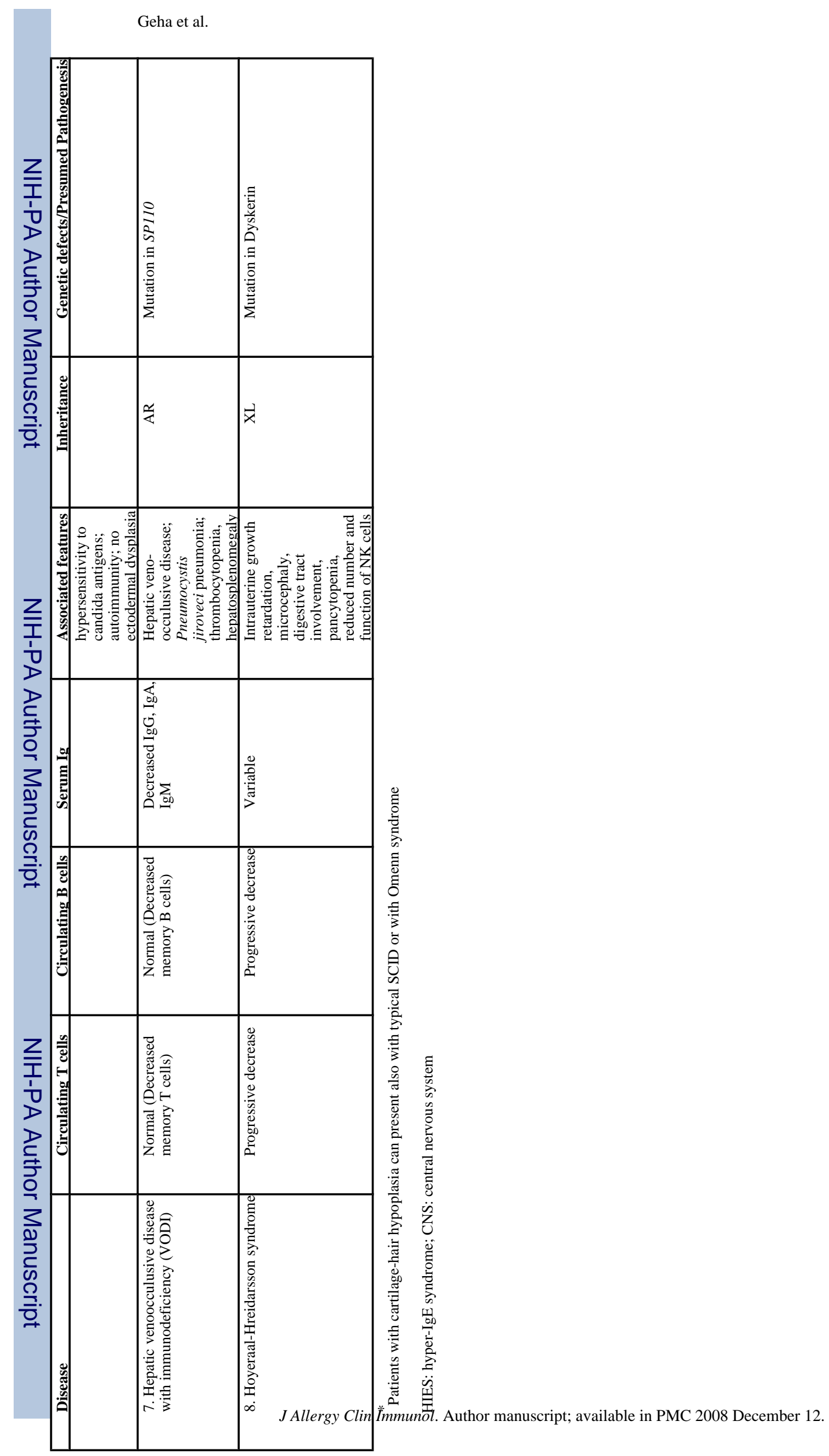

Page 11 


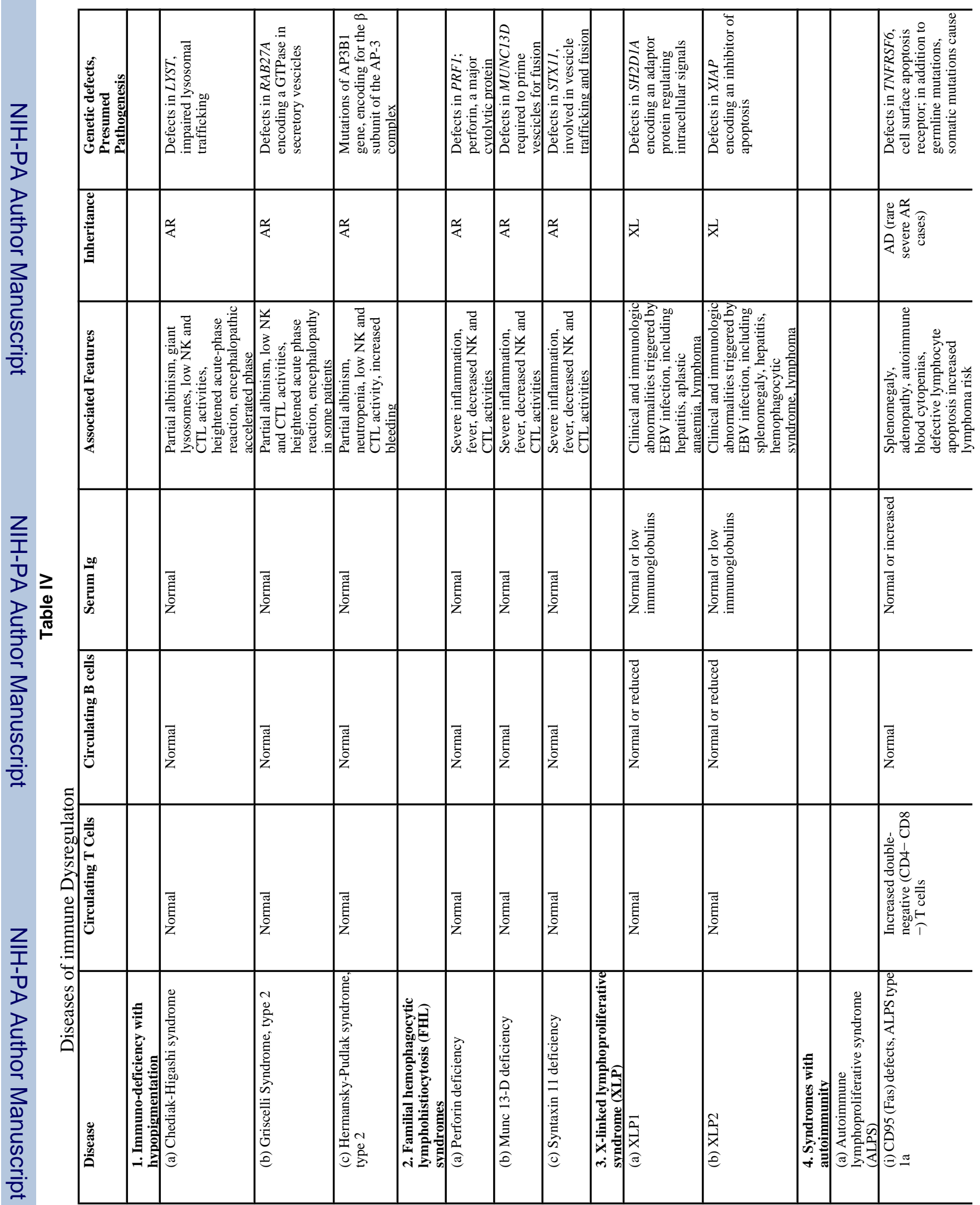




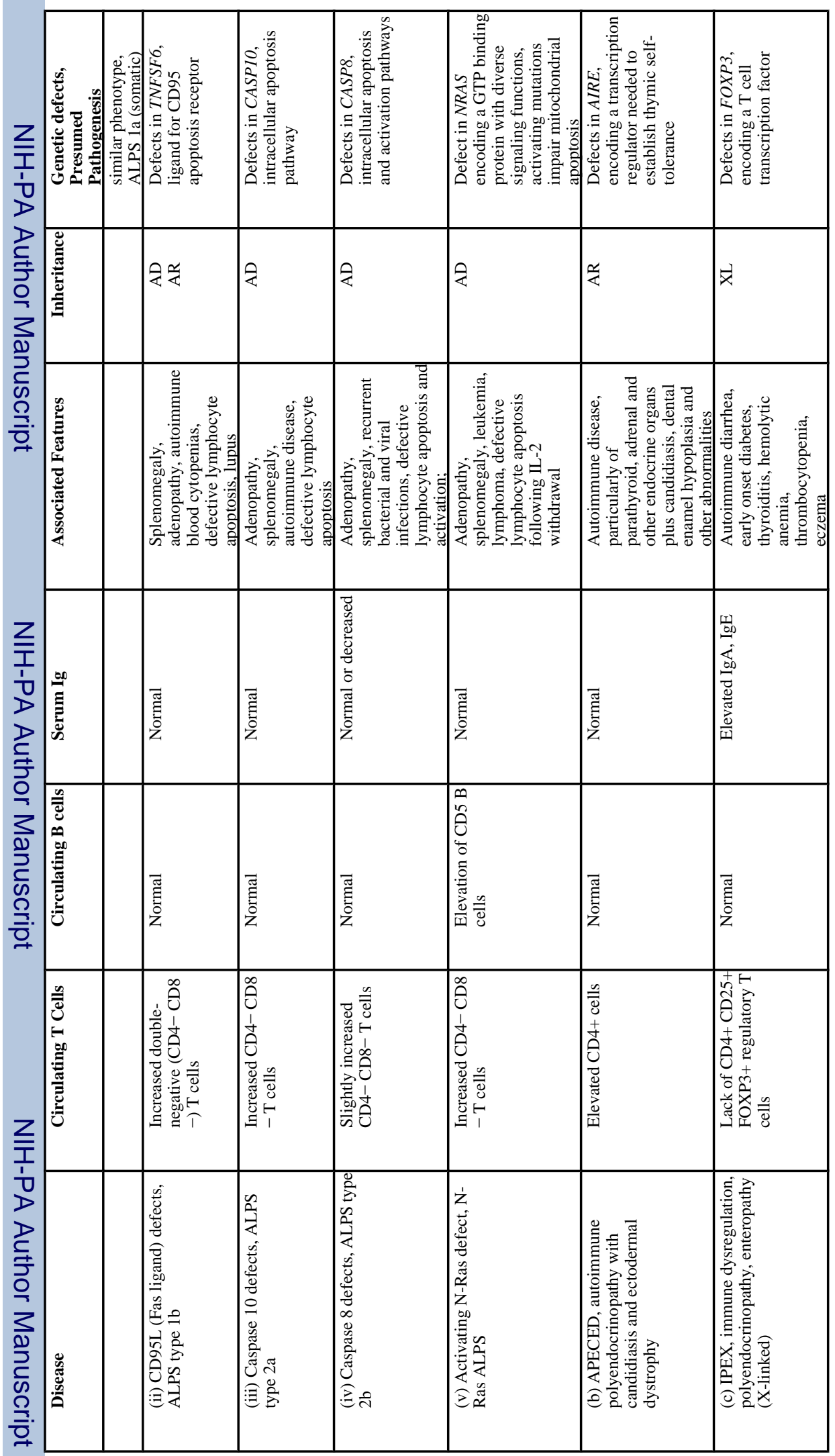




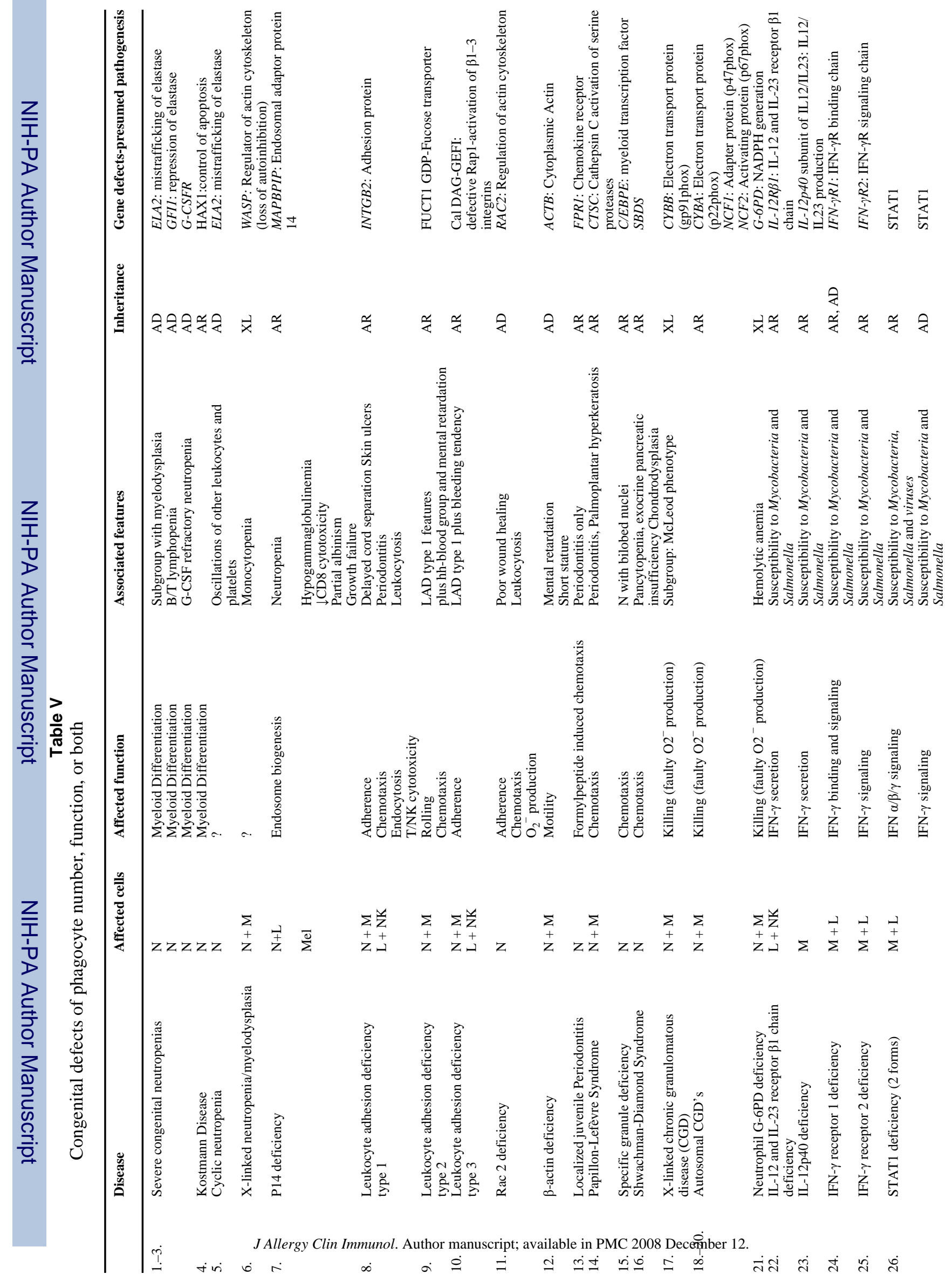




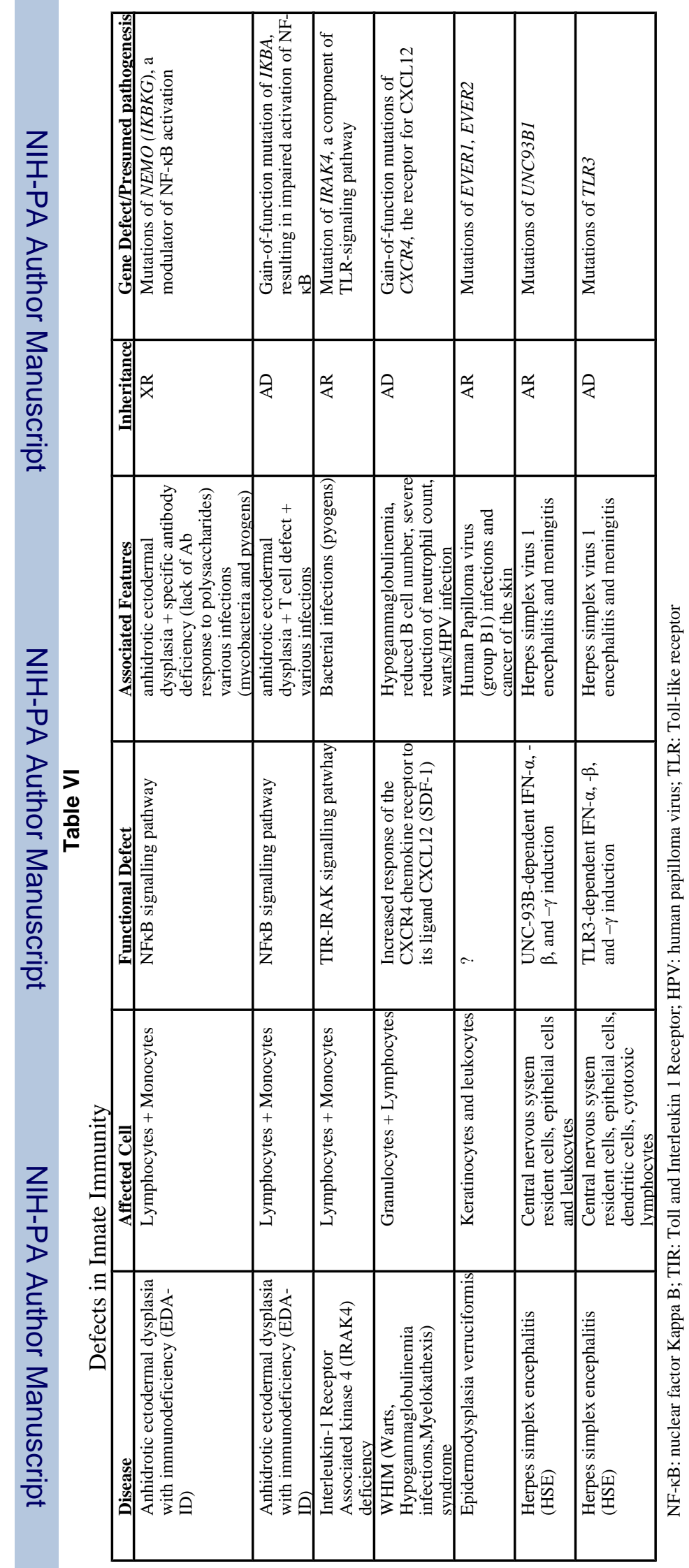

J Allergy Clin Immunol. Author manuscript; available in PMC 2008 December 12. 


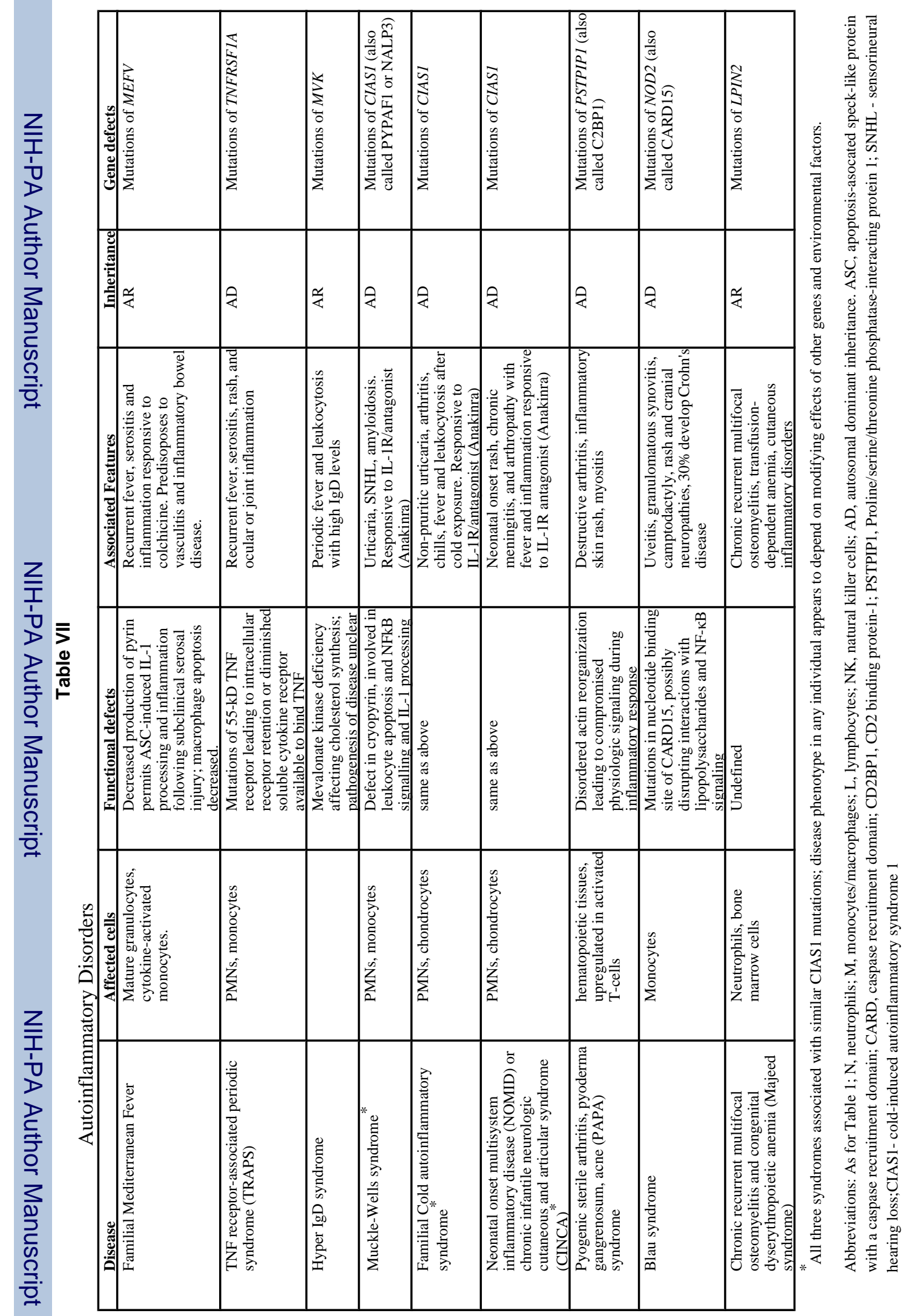


Complement deficiencies

Table VIII

\begin{tabular}{|c|c|c|c|c|}
\hline Disease & Functional Defect & Associated Features & Inheritance & Gene Defects \\
\hline C1q deficiency & $\begin{array}{l}\text {-Absent C hemolytic activity, } \\
\text { Defective MAC } \\
\text {-Faulty dissolution of immune } \\
\text { complexes } \\
\text {-Faulty clearance of apoptotic cells }\end{array}$ & $\begin{array}{l}\text { SLE-like syndrome, } \\
\text { rheumatoid disease, infections }\end{array}$ & $\mathrm{AR}$ & $\mathrm{C} 1 \mathrm{q}$ \\
\hline C1r deficiency $^{*}$ & $\begin{array}{l}\text {-Absent C hemolytic activity, } \\
\text { Defective MAC } \\
\text {-Faulty dissolution of immune } \\
\text { complexes }\end{array}$ & $\begin{array}{l}\text { SLE-like syndrome, } \\
\text { rheumatoid disease, infections }\end{array}$ & $\mathrm{AR}$ & $\mathrm{C} 1 \mathrm{r}^{*}$ \\
\hline C1s deficiency & -Absent $\mathrm{C}$ hemolytic activity & $\begin{array}{l}\text { SLE-like syndrome; multiple } \\
\text { autoimmune diseases }\end{array}$ & $\mathrm{AR}$ & $\mathrm{C} 1 \mathrm{~s}^{*}$ \\
\hline C4 deficiency & $\begin{array}{l}\text {-Absent C hemolytic activity, } \\
\text { Defective MAC } \\
\text {-Faulty dissolution of immune } \\
\text { complexes } \\
\text {-Defective humoral immune } \\
\text { response }\end{array}$ & $\begin{array}{l}\text { SLE-like syndrome, } \\
\text { rheumatoid disease, infections }\end{array}$ & $\mathrm{AR}$ & $\mathrm{C} 4 \mathrm{~A}$ and $\mathrm{C} 4 \mathrm{~B}^{\mathrm{S}}$ \\
\hline C2 deficiency ${ }^{* *}$ & $\begin{array}{l}\text {-Absent C hemolytic activity, } \\
\text { Defective MAC } \\
\text {-Faulty dissolution of immune } \\
\text { complexes }\end{array}$ & $\begin{array}{l}\text { SLE-like syndrome, vasculitis, } \\
\text { polymyositis, pyogenic } \\
\text { infections }\end{array}$ & AR & $\mathrm{C} 2^{* * *}$ \\
\hline C3 deficiency & $\begin{array}{l}\text {-Absent C hemolytic activity, } \\
\text { Defective MAC } \\
\text {-Defective Bactericidal activity } \\
\text {-Defective humoral immune } \\
\text { response }\end{array}$ & Recurrent pyogenic infections & AR & $\mathrm{C} 3$ \\
\hline C5 deficiency & $\begin{array}{l}\text {-Absent } \mathrm{C} \text { hemolytic activity, } \\
\text { Defective MAC } \\
\text {-Defective Bactericidal activity }\end{array}$ & Neisserial infections, SLE & $\mathrm{AR}$ & $\mathrm{C} 5$ \\
\hline C6 deficiency & $\begin{array}{l}\text {-Absent C hemolytic activity, } \\
\text { Defective MAC } \\
\text {-Defective Bactericidal activity }\end{array}$ & Neisserial infections, SLE & $\mathrm{AR}$ & C6 \\
\hline C7 deficiency & $\begin{array}{l}\text {-Absent C hemolytic activity, } \\
\text { Defective MAC } \\
\text {-Defective Bactericidal activity }\end{array}$ & $\begin{array}{l}\text { Neisserial infections, SLE, } \\
\text { vasculitis }\end{array}$ & $\mathrm{AR}$ & $\mathrm{C} 7$ \\
\hline C8a deficiency ${ }^{* * *}$ & $\begin{array}{l}\text {-Absent C hemolytic activity, } \\
\text { Defective MAC } \\
\text {-Defective Bactericidal activity }\end{array}$ & Neisserial infections, SLE & $\mathrm{AR}$ & $\mathrm{C} 8 \alpha$ \\
\hline C8b deficiency & $\begin{array}{l}\text {-Absent C hemolytic activity, } \\
\text { Defective MAC } \\
\text {-Defective Bactericidal activity }\end{array}$ & Neisserial infections, SLE & $\mathrm{AR}$ & $\mathrm{C} 8 \beta$ \\
\hline C9 deficiency & $\begin{array}{l}\text {-Reduced C hemolytic activity, } \\
\text { Defective MAC } \\
\text {-Defective Bactericidal activity }\end{array}$ & Neisserial infections ${ }^{* * * *}$ & $\mathrm{AR}$ & C9 \\
\hline $\mathrm{C} 1$ inhibitor deficiency & $\begin{array}{l}\text {-Spontaneous activation of the } \\
\text { complement pathway with } \\
\text { consumption of } \mathrm{C} 4 / \mathrm{C} 2 \\
\text {-Spontaneous activation of the } \\
\text { contact system with generation of } \\
\text { bradykinin from high molecular } \\
\text { weight kininogen }\end{array}$ & Hereditary angioedema & $\mathrm{AD}$ & $\mathrm{C} 1$ inhibitor \\
\hline Factor I deficiency & $\begin{array}{l}\text {-Spontaneous activation of the } \\
\text { alternative complement pathway } \\
\text { with consumption of } \mathrm{C} 3\end{array}$ & $\begin{array}{l}\text { Recurrent pyogenic infections, } \\
\text { glomerulonephritis, } \\
\text { hemolytic-uremic syndrome }\end{array}$ & $\overline{\mathrm{AR}}$ & Factor I \\
\hline Factor H deficiency & $\begin{array}{l}\text {-Spontaneous activation of the } \\
\text { alternative complement pathway } \\
\text { with consumption of } \mathrm{C} 3\end{array}$ & $\begin{array}{l}\text { Hemolytic-uremic syndrome, } \\
\text { membranoproliferative } \\
\text { glomerulonephritis }\end{array}$ & $\mathrm{AR}$ & Factor $\mathrm{H}$ \\
\hline Factor D deficiency & $\begin{array}{l}\text {-Absent hemolytic activity by the } \\
\text { alternate pathway }\end{array}$ & Neisserial infection & $\overline{\mathrm{AR}}$ & Factor D \\
\hline Properdin deficiency & $\begin{array}{l}\text {-Absent hemolytic activity by the } \\
\text { alternate pathway }\end{array}$ & Neisserial infection & $\mathrm{XL}$ & Properdin \\
\hline MBP deficiency ${ }^{* * * * * *}$ & $\begin{array}{l}\text {-Defective mannose recognition } \\
\text {-Defective hemolytic activity by } \\
\text { the lectin pathway. }\end{array}$ & $\begin{array}{l}\text { Pyogenic infections with very } \\
\text { low penetrance mostly } \\
\text { asymptamatic }\end{array}$ & AR & MBP ${ }^{* * *}$ \\
\hline MASP2 deficiency ${ }^{* * * * * * *}$ & $\begin{array}{l}\text {-Absent hemolytic activity by the } \\
\text { lectin pathway }\end{array}$ & $\begin{array}{l}\text { SLE syndrome, pyogenic } \\
\text { infection }\end{array}$ & AR & MASP2 \\
\hline $\begin{array}{l}\text { Complement Receptor } 3 \text { (CR3) } \\
\text { deficiency }\end{array}$ & -see LAD1 in Table V, above & & AR & INTGB2 \\
\hline $\begin{array}{l}\text { Membrane Cofactor Protein (CD46) } \\
\text { deficiency }\end{array}$ & $\begin{array}{l}\text {-Inhibitor of complement alternate } \\
\text { pathway, decreased C } 3 \mathrm{~b} \text { binding }\end{array}$ & $\begin{array}{l}\text { Glomerulonephritis, atypical } \\
\text { hemolytic uremic syndrome }\end{array}$ & $\mathrm{AD}$ & $\mathrm{MCP}$ \\
\hline $\begin{array}{l}\text { Membrane Attack Complex Inhibitor } \\
\text { (CD59) deficiency }\end{array}$ & $\begin{array}{l}\text {-Erythrocytes highly susceptible to } \\
\text { complement-mediated lysis }\end{array}$ & Hemolytic anemia, thrombosis & $\mathrm{AR}$ & CD59 \\
\hline
\end{tabular}




\begin{tabular}{|l|l|l|l|l|}
\hline Disease & Functional Defect & Associated Features & Inheritance & Gene Defects \\
\hline Paroxysmal nocturnal hemoglobinuria & -Complement-mediated hemolysis & Recurrent hemolysis & Acquired X-linked mutation & PIGA \\
\hline
\end{tabular}

* The $\mathrm{C} 1 \mathrm{r}$ and $\mathrm{C} 1 \mathrm{~s}$ genes are located within $9.5 \mathrm{~kb}$ of each other. In many cases of C1r deficiency, $\mathrm{C} 1 \mathrm{~s}$ is also deficient.

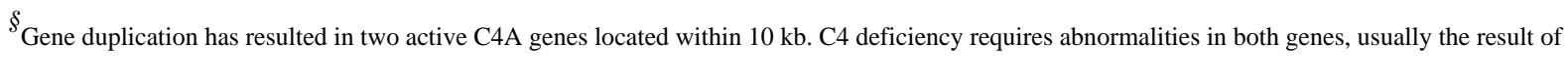
deletions.

** Type 1 C2 deficiency is in linkage disequilibrium with HLA-A25, B18 and -DR2 and complotype, SO42 (slow variant of Factor B, absent C2, type 4 $\mathrm{C} 4 \mathrm{~A}$, type $2 \mathrm{C} 4 \mathrm{~B}$ ) and is common in Caucasians (about 1 per 10,000). It results from a 28-bp deletion resulting in a premature stop codon in the $\mathrm{C} 2$ gene; $\mathrm{C} 2$ mRNA is not produced. Type $2 \mathrm{C} 2$ deficiency is very rare and involves amino acid substitutions which result in $\mathrm{C} 2$ secretory block.

$* * *$

C8alpha deficiency is always associated with C8gamma deficiency. The gene encoding C8gamma maps to chromosome 9 and is normal. C8gamma is covalently bound to C8alpha.

$* * * *$

Association is weaker than with C5, C6, C7 and C8 deficiencies. C9 deficiency occurs in about 1 per 1,000 Japanese.

***** Population studies reveal no detectable increase in infections in MBP deficient adults.

$* * * * * *$

A single patient.

Abbreviations: MAC= Membrane attack complex SLE: systemic lupus erythematosus; MBP: Mannose binding Protein; MASP-2: MBP associated serine protease 2 . 